\title{
Role of government policy in nutrition-barriers to and opportunities for healthier eating
}

\author{
Dariush Mozaffarian and colleagues review strategies governments can use to improve \\ nutrition and health
}

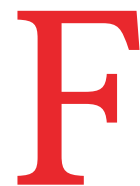

or most of human history including much of the 20th century, insufficient food was the greatest nutritional challenge. To tackle this, government sought to stimulate the production and distribution of as much inexpensive food as possible, in particular starchy (high carbohydrate) staple commodities and their shelf stable processed products. At the time, a global pandemic of obesity and chronic diseases from the widespread availability of inexpensive, unhealthy food was inconceivable.

The relatively recent rise of diet related chronic diseases including obesity, type 2 diabetes, cardiovascular diseases, and several cancers is at least partly a byproduct of these historical approaches and the responses of industry and consumers. A separate article in this series reviews the trends in nutrition science over this period, ${ }^{1}$ which have slowly shifted focus from undernutrition defined by calories and micronutrient deficiency to food based

\section{KEY MESSAGES}

- Despite the rise in diet related chronic diseases and associated costs, government policies continue to have conventional perspectives on agricultural production, industry support, food security, economics, and trade

- New, evidence informed government nutrition policies are needed to reduce the risk of chronic diseases and reduce dietary and health inequities

- The complementary and synergistic nature of different policies supports the need for an integrated, multicomponent government strategy that uses and adapts existing structures and systems

- To translate evidence into action, governments must have the appropriate knowledge, capacity, and will to act and the governance and partnership to support action

- Specific actions by major stakeholders should promote, facilitate, and complement policy efforts

- Strong government policy is essential to help achieve a healthy, profitable, equitable and sustainable food system that benefits all diet patterns and overall health effects of the food supply.

Even with the unprecedented rise in diet related chronic diseases, government policies have continued to emphasise agricultural production of staple commodities and support for the food industry motivated by conventional perspectives on food security, economics, and trade. While undernutrition has improved with government supported systems changes such as agricultural development and fortification programmes, ${ }^{1}$ government has tended to use educational policy measures directed at individuals in response to the rise in chronic diseases. Such measures aim to influence diet quality by emphasising personal responsibility and choice through dietary guidelines, food labels, menu labelling, and clinical counselling.

Growing evidence makes clear that multiple, complex factors beyond personal decisions strongly influence dietary choices and patterns (fig 1). ${ }^{2-7}$ Even at the individual level, dietary habits are determined by personal preference and also age, gender, culture, education, income, health status, and nutritional and cooking knowledge and skills. ${ }^{8}$ Psychological influences include attitudes to food and health, incentives, motivation, and values. ${ }^{9}$ Food preferences may also be influenced by early life exposures, including the mother's diet during pregnancy, infant feeding practices, and foods consumed in early childhood. ${ }^{10-12}$ Broader sociocultural determinants of personal choices include household lifestyle patterns such as television watching and sleep, ${ }^{13-16}$ family and community norms, social pressures, social class, social networks, and race/ ethnicity. ${ }^{17}$ The local environment also plays an important role..$^{2-7}$

Importantly, wider commercial pressures also affect consumer choice, including food packaging, marketing, advertising, and sociocultural perceptions of norms, status, and prestige. ${ }^{18-20}$ Each of these individual determinants is shaped by, and in turn shapes, much broader drivers of food choice such as food industry formulations and globalisation, farming policy and production practices, national and international trade agreements, and ecosystem influences. ${ }^{2122}$
Uncoordinated, these many influences are powerful and are nearly insurmountable barriers to making healthy dietary choices for many people worldwide. They can introduce health inequities, and sustain or deepen existing ones. However, with thoughtful, evidence informed policy, each of these factors also provides an opportunity for governments to support improvements in diets, health, wellbeing, and equity.

Based on advances in behavioural and policy science, we review strategies and approaches that governments can use to directly improve nutrition. We appreciate that other nutrition policy frameworks have been considered..$^{5-7} \mathrm{We}$ focus on a broad range of interventions and nutrition policies and discuss their strengths, limitations, uncertainties, and recommendations.

Types of policy interventions

Governments can use a spectrum of policies from voluntary to mandatory. These include a bill (proposed law), law/act/statute (approved by legislative and executive branches), agency implementation (interpretation, application, regulation), court decision, guideline (recommendation, not mandatory), or directive (internal to an institution).

By their nature, public health concerns such as nutrition are multifactorial. Even single or simple interventions induce effects within complex webs of interactions. ${ }^{23} \mathrm{We}$ focus on policies directly targeting nutrition rather than more indirect mechanisms related to, for example, trade, farming, food waste, general education, and economic empowerment. Each policy strategy can be classified according to different related characteristics (box 1) that need to be considered and defined in government policy design. $^{24}$

\section{Government food policy strategies}

For the different government policy actions, we present a summary of their strengths, limitations, uncertainties, and recommendations (table 1). Implementation of policy actions must be accompanied by systematic surveillance and evaluation to assess progress and guide further efforts.

Some key findings can be highlighted. For example, population education and 


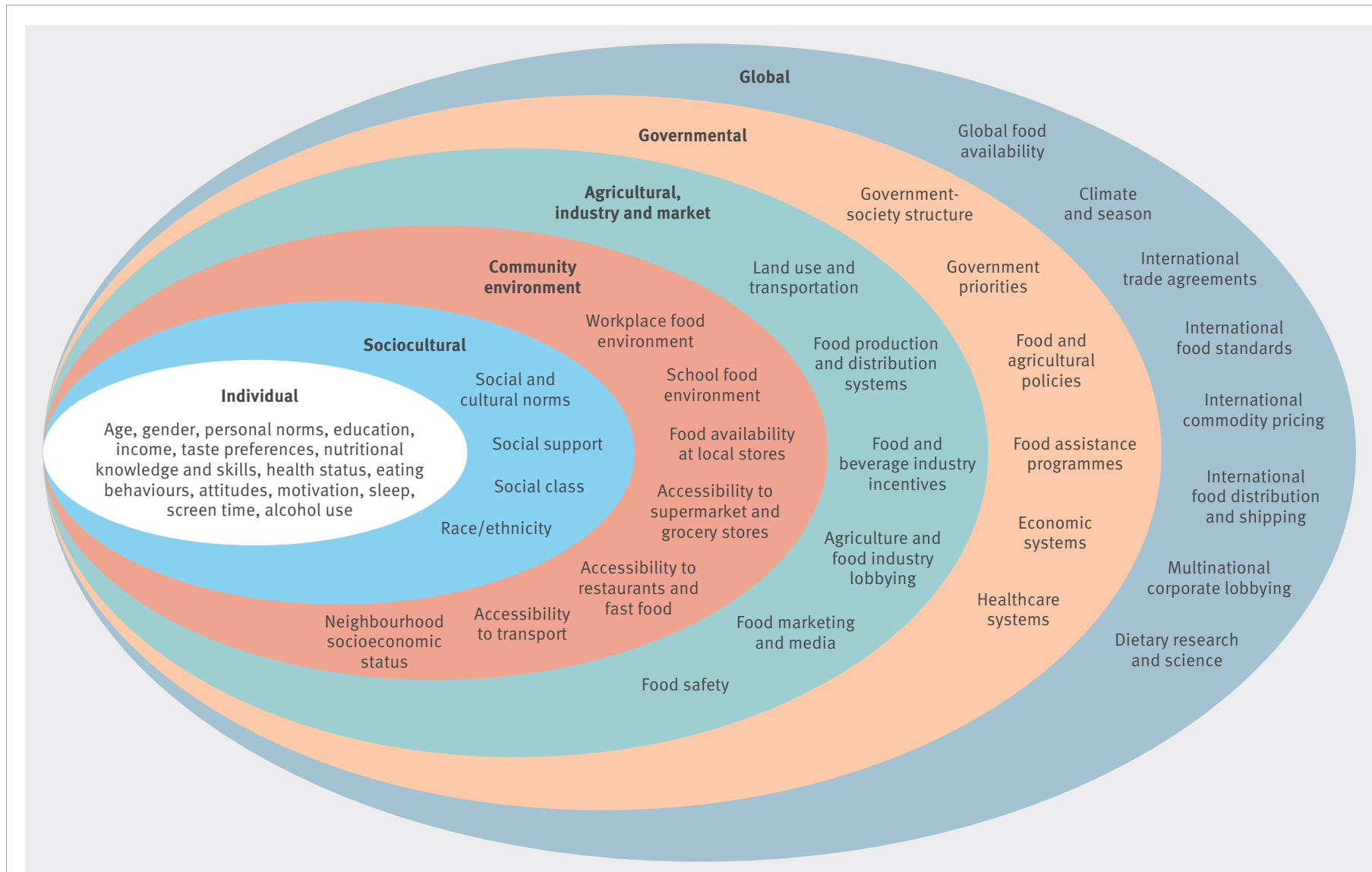

Fig 1 | Multilayered influences beyond personal knowledge and preference alter food choices. Government can consider these influences as potential targets, barriers, facilitators, and effect modifiers of food policies. Reproduced with permission from Ashfin et al ${ }^{2}$

point-of-purchase labelling are widely and increasingly used. Such "soft" policies place most responsibility on the individual consumer, with which industry is often more comfortable. The effectiveness of such policies on behaviour change overall and in specific population subgroups has been variable and they may have smaller effects in marginalised groups. ${ }^{347980}$ However, such approaches can also promote industry reformulations, which may have an important effect on longer term health beyond immediate consumer behaviour. ${ }^{34}$ Overall, such approaches can be valuable as part of a broader, multicomponent government food and nutrition strategy.

In contrast to education and information, fiscal incentives and disincentives aimed at consumers, producers, and retailers have more consistent evidence of effectiveness. ${ }^{2-7}$ Disincentives can include excise or sales taxes on unhealthy items such as sugar sweetened beverages and junk food ${ }^{38-40}$ or removal of industry tax benefits for development and marketing of unhealthy products. Disincentives on specific foods can be politically difficult, however, the rapid international expansion of taxes on sugar sweetened beverages shows the growing acceptance of this approach. ${ }^{81}$ Such taxes can be financially regressive for lower income individuals, but progressive because of benefits to nutrition and health. To reduce financial regressivity and increase the health effect, tax revenues can be used for other health promotion strategies including retail, manufacturing, or agricultural incentives to reduce the

\section{Box 1: Classification of policy interventions}

- Level-city, state, or national government; international agencies; organisations (eg, school, worksite, healthcare facility); local neighbourhoods and communities

- Target-consumer, organisation (eg, school, worksite), health system, production (farming, agriculture), industry (manufacturer, retailer, restaurant)

- Domain-population education (eg, dietary guidelines, mass media), point-of-purchase information, fiscal policies, food quality standards, built environment changes, research and innovation

- Mechanism-altering consumer preferences or choice, food formulations, or food availability and accessibility

price of healthier food products..$^{4142}$ Rather than being punitive, economic incentives and disincentives "normalise" the market by partly bringing the prices of different foods closer to their true societal cost.

Procurement and quality standards are relatively sustainable, low cost strategies for government to implement. For instance, limitations or standards on trans fat and sodium have been implemented in many countries and similar standards being considered for free or added sugars. ${ }^{2-7}$ Because governments are often one of the largest buyers of food, nutrition procurement standards should be set for all their food purchases across agencies and programsmes. ${ }^{82}$ In addition, vanguard local and national quality standards should be implemented on the use of food additives by industry such as trans fat, sodium, and sugar. ${ }^{45-47 ~ 83-85}$

Schools and worksites are natural and complementary settings for effective nutrition policies..$^{2-7}$ In schools, after school, and early childcare programmes, government should promote nutrition standards for both onsite meals and competitive foods as low cost, sustainable interventions-examples include standards in the US, Canada, Mexico, Europe, and New Zealand. ${ }^{49}$ Free or low price provision of fruits and vegetables, farm to school 
Table 1 | Key government related food policy strategies to improve diet quality

\begin{tabular}{|c|c|c|c|c|c|}
\hline Policy strategy & Examples & Strengths & Limitations & Uncertainties & Recommendations \\
\hline $\begin{array}{l}\text { Population } \\
\text { education }\end{array}$ & $\begin{array}{l}\text { National dietary } \\
\text { guidelines. }{ }^{25} \text { Mass } \\
\text { media “ } 5 \text { a day for better } \\
\text { health" programme. } \\
\text { Population education } \\
\text { components of the North } \\
\text { Karelia project. }{ }^{27} \text { Use } \\
\text { of cultural influencers. } \\
\text { School curriculums } \\
\text { focused on nutrition and } \\
\text { culinary skills }\end{array}$ & $\begin{array}{l}\text { Dietary guidelines can } \\
\text { be promoted across the } \\
\text { population }{ }^{28} \text { and be } \\
\text { supported by rigorous } \\
\text { and transparent reviews } \\
\text { of evidence. }{ }^{29} \text { Dietary } \\
\text { guidelines can directly } \\
\text { influence government } \\
\text { food service and } \\
\text { assistance programmes. } \\
\text { They are a "soft" policy } \\
\text { with which industry is } \\
\text { more comfortable and } \\
\text { can indirectly promote } \\
\text { industry reformulations }\end{array}$ & $\begin{array}{l}\text { Mass media promotion of } \\
\text { guidelines is costly, often } \\
\text { with limited reach and } \\
\text { sustainability. Large gaps } \\
\text { exist between national dietary } \\
\text { guidelines and actual public } \\
\text { diets, indicating limited } \\
\text { overall effectiveness. After } \\
\text { decades of policy use, obesity } \\
\text { and other chronic diseases } \\
\text { continue to rise globally. } \\
\text { Guidelines have smaller } \\
\text { effects in marginalised } \\
\text { subgroups }\end{array}$ & $\begin{array}{l}\text { Optimal conditions in which } \\
\text { population education can } \\
\text { effect behaviour change, } \\
\text { overall and in specific } \\
\text { subgroups, remains unclear. } \\
\text { Relative sustainability } \\
\text { and cost effectiveness } \\
\text { are uncertain especially } \\
\text { compared with other } \\
\text { environmental and systems } \\
\text { based strategies }\end{array}$ & $\begin{array}{l}\text { Can be helpful if accompanied by } \\
\text { other measures, and if backed by } \\
\text { government or semi-official bodies } \\
\text { with influence. Cultural influencers } \\
\text { (eg, celebrities, athletes, chefs) } \\
\text { can help change social norms. } \\
\text { Guidelines must be consistent with } \\
\text { other official messages about food } \\
\text { and health }\end{array}$ \\
\hline $\begin{array}{l}\text { Point-of-purchase } \\
\text { labelling }\end{array}$ & $\begin{array}{l}\text { Food package nutrition } \\
\text { fact panels, }{ }^{30} \text { health } \\
\text { claims. Restaurant calorie } \\
\text { menu labelling. }{ }^{3132} \text { Front- } \\
\text { of-pack traffic light. } \\
\text { "Black box" warning } \\
\text { labels in Chile }\end{array}$ & $\begin{array}{l}\text { Such information can } \\
\text { encourage industry to } \\
\text { reformulate, especially } \\
\text { for additives such } \\
\text { as sodium, trans fat, } \\
\text { and sugar. }{ }^{34} \text { Point-of- } \\
\text { purchase strategies } \\
\text { can be useful when } \\
\text { consumers have } \\
\text { knowledge or are more } \\
\text { aware or motivated } \\
\text { because of personal } \\
\text { circumstances (eg, } \\
\text { pregnancy, older age, } \\
\text { with diabetes) }\end{array}$ & $\begin{array}{l}\text { Evidence is mixed about } \\
\text { effects on consumer } \\
\text { behaviour, perhaps varying } \\
\text { with nutrient or food targets. }{ }^{34} \\
\text { Many approaches have not } \\
\text { been rigorously studied or } \\
\text { implemented and thoroughly } \\
\text { evaluated. Confusion and } \\
\text { controversy exist about } \\
\text { optimal target nutrients/ } \\
\text { metrics. Consumer attention } \\
\text { at point of purchase is slight; } \\
\text { distractions can be high. }{ }^{35} \\
{ }^{36} \text { Official labels can be } \\
\text { confused by product branding }\end{array}$ & $\begin{array}{l}\text { Optimal dietary factors } \\
\text { or standards to target are } \\
\text { not well established (eg, } \\
\text { many point-of-purchase } \\
\text { approaches continue to } \\
\text { include outdated targets } \\
\text { such as total fat, total } \\
\text { calories). Consumer } \\
\text { attention and awareness } \\
\text { may not translate to } \\
\text { behaviour. Disparities might } \\
\text { be exacerbated because } \\
\text { of smaller effects on } \\
\text { disadvantaged groups }\end{array}$ & $\begin{array}{l}\text { These should be promoted } \\
\text { because they are within the } \\
\text { "consumer market" model. } \\
\text { Promising options include front- } \\
\text { of-pack (eg, UK, New Zealand), } \\
\text { warning labels (eg, Chile, New } \\
\text { York City's sodium menu label, } \\
\text { California's proposed warning } \\
\text { label on sugar sweetened } \\
\text { beverages). For most such actions, } \\
\text { relative healthfulness of different } \\
\text { foods must be appropriately } \\
\text { classified, perhaps using systems } \\
\text { that combine food category } \\
\text { classifications with multilevel } \\
\text { nutrient criteria }{ }^{3738}\end{array}$ \\
\hline $\begin{array}{l}\text { Fiscal incentives } \\
\text { and disincentives }\end{array}$ & $\begin{array}{l}\text { National soda and junk } \\
\text { food taxes. }{ }^{38-40} \text { Subsidies } \\
\text { for fruits and vegetables } \\
\text { in national food } \\
\text { assistance programmes. }{ }^{41} \\
{ }^{42} \text { Agricultural incentives } \\
\text { for berry production }{ }^{27}\end{array}$ & $\begin{array}{l}\text { Price has a strong } \\
\text { influence on food } \\
\text { choice. Such effects } \\
\text { may also be stronger } \\
\text { in low income groups, } \\
\text { helping to reduce } \\
\text { nutrition and health } \\
\text { disparities. Publicity } \\
\text { around price incentives } \\
\text { and disincentives can } \\
\text { bring about additional } \\
\text { changes in attitudes and } \\
\text { intake. }\end{array}$ & $\begin{array}{l}\text { Consumption change in some } \\
\text { foods may have unpredictable } \\
\text { effects on overall dietary } \\
\text { quality, depending on } \\
\text { substitutes. Relatively large } \\
\text { price differences may be } \\
\text { needed to be effective and } \\
\text { strong government support. } \\
\text { Taxes and other financial } \\
\text { disincentives often create } \\
\text { strong opposition and } \\
\text { lobbying by industry }\end{array}$ & $\begin{array}{l}\text { How important are } \\
\text { additional indirect effects } \\
\text { on substitutes and } \\
\text { complements (other foods)? }\end{array}$ & $\begin{array}{l}\text { Fiscal incentives are effective and } \\
\text { should be used by governments. } \\
\text { This market based approach helps } \\
\text { bring the price of foods closer to } \\
\text { their true societal cost, including } \\
\text { direct and indirect costs on health } \\
\text { (and potentially the environment). } \\
\text { Disincentives should be paired } \\
\text { with incentives to reduce financial } \\
\text { regressivity, maximise health } \\
\text { benefits, and help reduce industry } \\
\text { opposition }\end{array}$ \\
\hline $\begin{array}{l}\text { Food assistance } \\
\text { programmes }\end{array}$ & $\begin{array}{l}\text { Income based or other } \\
\text { conditional food vouchers } \\
{\text { or cash transfers, }{ }^{43} \text { school }}_{\text {meals, supplementation }} \\
\text { programmes }\end{array}$ & $\begin{array}{l}\text { These improve } \\
\text { purchasing power and } \\
\text { access of low income } \\
\text { groups, helping to tackle } \\
\text { disparities. They use } \\
\text { existing systems for } \\
\text { improving nutrition, and } \\
\text { align poverty reduction } \\
\text { with health promotion } \\
\text { and healthcare } \\
\text { programmes }\end{array}$ & $\begin{array}{l}\text { These often have limited } \\
\text { guidelines or standards } \\
\text { around diet quality and } \\
\text { health. Governments } \\
\text { may consider them costly } \\
\text { welfare programmes; short } \\
\text { and long term benefits on } \\
\text { health, healthcare costs, and } \\
\text { productivity are often not } \\
\text { estimated }\end{array}$ & $\begin{array}{l}\text { The appropriate balance } \\
\text { between participant choice } \\
\text { and health promotion is } \\
\text { unclear }\end{array}$ & $\begin{array}{l}\text { All government food assistance } \\
\text { programmes should have } \\
\text { mechanisms, standards, and } \\
\text { incentives for healthful, nutritious, } \\
\text { and culturally appropriate } \\
\text { choices, and also align with } \\
\text { health promotion and healthcare } \\
\text { programming }\end{array}$ \\
\hline $\begin{array}{l}\text { Procurement } \\
\text { nutrition standards }\end{array}$ & $\begin{array}{l}\text { Nutrition standards } \\
\text { for food purchases for } \\
\text { government offices, } \\
\text { public schools, the } \\
\text { military, food assistance } \\
\text { programmes, and other } \\
\text { government funded } \\
\text { organisations }\end{array}$ & $\begin{array}{l}\text { Governments are } \\
\text { often large employers } \\
\text { and food purchasers } \\
\text { in their region. They } \\
\text { are low cost and } \\
\text { sustainable. In cases } \\
\text { of high coverage food } \\
\text { assistance programmes, } \\
\text { nutrition standards } \\
\text { may improve diets in } \\
\text { large proportions of the } \\
\text { population, including } \\
\text { disadvantaged groups }\end{array}$ & $\begin{array}{l}\text { Whereas setting standards } \\
\text { is low cost, following them } \\
\text { may substantially increase } \\
\text { food purchasing costs where } \\
\text { government budgets are } \\
\text { limited. }\end{array}$ & $\begin{array}{l}\text { Effects on diets are unclear } \\
\text { eg, compensatory dietary } \\
\text { changes may occur outside } \\
\text { the organisation. Optimal } \\
\text { dietary factors or standards } \\
\text { to target are not well } \\
\text { established, especially for } \\
\text { packaged foods }\end{array}$ & $\begin{array}{l}\text { Nutrition standards should guide } \\
\text { all food purchases for government } \\
\text { offices, public schools, the military, } \\
\text { food assistance programmes, } \\
\text { and other government funded } \\
\text { organisations. National food } \\
\text { assistance programmes can be } \\
\text { used for diet quality and nutrition }\end{array}$ \\
\hline $\begin{array}{l}\text { Industry quality } \\
\text { standards }\end{array}$ & $\begin{array}{l}\text { Mandatory or government } \\
\text { recommended limits } \\
\text { and standards on use of } \\
\text { additives, such as trans } \\
\text { fat, salt, and sugar }{ }^{45} \\
\text { (eg, limits on use of } \\
\text { industrial trans fat, }{ }^{46} \text { UK } \\
\text { salt reduction programme } \\
\text { including public } \\
\text { awareness }^{47} \text { ) }\end{array}$ & $\begin{array}{l}\text { These are low cost, } \\
\text { sustainable, and } \\
\text { more effective than } \\
\text { consumer education } \\
\text { and information. }{ }^{48} \text { They } \\
\text { can be voluntary or } \\
\text { mandatory; regulation } \\
\text { and laws are stronger } \\
\text { than voluntary guidance } \\
\text { from government. }\end{array}$ & $\begin{array}{l}\text { The food industry promotion } \\
\text { of developing their own } \\
\text { internal standards, and } \\
\text { staunch opposition to } \\
\text { government standards } \\
\text { (see box 2). "Nanny state" } \\
\text { concerns }\end{array}$ & $\begin{array}{l}\text { Optimal targets for certain } \\
\text { categories of product (eg, } \\
\text { to balance health versus } \\
\text { functionality, safety, and } \\
\text { industry cost) are not known. } \\
\text { Differences between 'natural' } \\
\text { and 'industry' ingredients } \\
\text { (eg, for sugar) are unclear. } \\
\text { How to overcome political } \\
\text { challenges is uncertain }\end{array}$ & $\begin{array}{l}\text { These should be implemented } \\
\text { by governments. They are most } \\
\text { relevant, practical, and politically } \\
\text { feasible for additives (eg, trans fat, } \\
\text { sodium, and added sugar) }\end{array}$ \\
\hline
\end{tabular}




\begin{tabular}{|c|c|c|c|c|c|}
\hline Policy strategy & Examples & Strengths & Limitations & Uncertainties & Recommendations \\
\hline $\begin{array}{l}\text { Schools, after } \\
\text { school and early } \\
\text { child care }\end{array}$ & $\begin{array}{l}\text { Meal nutrition } \\
\text { standards. }{ }^{49} \text { Nutrition } \\
\text { standards for competitive } \\
\text { food (products available } \\
\text { outside regular meal } \\
\text { times). }{ }^{49} \text { Free/reduced } \\
\text { price provision of F\&V. }{ }^{49} \\
\text { School gardens, farm } \\
\text { to school programmes. } \\
\text { Nutrition education }\end{array}$ & $\begin{array}{l}\text { With 1-2 meals eaten } \\
\text { onsite each day, } \\
\text { schools, after school, } \\
\text { and early child care } \\
\text { programmes are natural } \\
\text { places to promote } \\
\text { healthier eating in } \\
\text { children. Nutrition } \\
\text { standards for onsite } \\
\text { meals and competitive } \\
\text { foods are low cost and } \\
\text { sustainable }\end{array}$ & $\begin{array}{l}\text { Often budgets are limited } \\
\text { for healthier meals. Loss of } \\
\text { revenue is feared with strong } \\
\text { standards for competitive } \\
\text { foods, eg, from industry } \\
\text { vending machines. Direct } \\
\text { F\&V provision, farm to school } \\
\text { programmes, and gardens are } \\
\text { more costly }\end{array}$ & $\begin{array}{l}\text { Long term effects and cost- } \\
\text { benefits are assumed but } \\
\text { not yet rigorously evaluated } \\
\text { or established }\end{array}$ & $\begin{array}{l}\text { Government should set strong } \\
\text { nutrition standards for school, } \\
\text { after school, and early child } \\
\text { care meals and competitive } \\
\text { foods. Additional school } \\
\text { based interventions should be } \\
\text { implemented if fiscally feasible }\end{array}$ \\
\hline Worksite wellness & $\begin{array}{l}\text { Procurement standards } \\
\text { for cafeterias and } \\
\text { vending. Comprehensive } \\
\text { wellness programmes. } \\
\text { New technology } \\
\text { platforms and incentives } \\
\text { for healthier eating. }{ }^{50} \\
\text { Built environment } \\
\text { changes to encourage } \\
\text { behavioural changes }^{51.53}\end{array}$ & $\begin{array}{l}\text { Time spent at work } \\
\text { make worksites a } \\
\text { natural place to } \\
\text { promote healthier } \\
\text { eating. Can focus on } \\
\text { at-risk groups and high } \\
\text { risk employees. }{ }^{54} \mathrm{Can} \\
\text { reduce absenteeism and } \\
\text { medical costs. }{ }^{55} \text { Can be } \\
\text { paired with government } \\
\text { tax incentives for } \\
\text { wellness programmes } \\
\text { in private insurance and } \\
\text { worksites }\end{array}$ & $\begin{array}{l}\text { With increased turnover of } \\
\text { the workforce, long term } \\
\text { employment is becoming rare, } \\
\text { reducing financial incentives } \\
\text { for employers to improve } \\
\text { long term health of their } \\
\text { employees. Occupational } \\
\text { health services tend to focus } \\
\text { on immediate effects such as } \\
\text { injuries }\end{array}$ & $\begin{array}{l}\text { Long term effectiveness in } \\
\text { improving diet is unclear; } \\
\text { most evidence comes from } \\
\text { shorter term intervention } \\
\text { studies (up to one year). Few } \\
\text { rigorous cost effectiveness } \\
\text { analyses have been done, } \\
\text { making it hard to promote } \\
\text { the business case }\end{array}$ & $\begin{array}{l}\text { Government guidelines or fiscal } \\
\text { incentives are needed to promote } \\
\text { the inclusion and evaluation } \\
\text { of nutrition in private employer } \\
\text { worksite wellness programmes } \\
\text { and insurance plans }\end{array}$ \\
\hline Health systems & $\begin{array}{l}\text { Integrated lifestyle } \\
\text { interventions by } \\
\text { multidisciplinary } \\
\text { teams (eg, Diabetes } \\
\text { Prevention Program }{ }^{56} \text { ). } \\
\text { Medically tailored } \\
\text { meals for patients with } \\
\text { complex illness. }{ }^{5758} \\
\text { F\&V prescriptions. }{ }^{59} \\
\text { Nutrition counselling } \\
\text { during pregnancy } \\
\text { and early childhood. } \\
60-62 \text { Quality metrics and } \\
\text { reimbursement systems } \\
\text { that reward community } \\
\text { engagement to address } \\
\text { upstream causes of poor } \\
\text { health. }{ }^{63} \text { Integration of } \\
\text { healthcare with public } \\
\text { health. }{ }^{64} \text { Worksite } \\
\text { wellness and community } \\
\text { leadership }{ }^{65} 66\end{array}$ & $\begin{array}{l}\text { Consumers and policy } \\
\text { makers continue to } \\
\text { value and respect } \\
\text { healthcare providers. } \\
\text { Approaches can be } \\
\text { synchronised with } \\
\text { new care delivery } \\
\text { investments in social } \\
\text { determinants of } \\
\text { health and community } \\
\text { infrastructure. Health } \\
\text { systems cannot be the } \\
\text { only solution but they } \\
\text { have an important role. } \\
\text { Government and private } \\
\text { healthcare systems } \\
\text { often have considerable } \\
\text { resources which can be } \\
\text { used for better nutrition, } \\
\text { returning value and } \\
\text { savings to the system. } \\
\text { Hospitals are often main } \\
\text { community employers } \\
\text { with an important local } \\
\text { voice }\end{array}$ & $\begin{array}{l}\text { The health system has } \\
\text { limited reach, influence, } \\
\text { and relevance for daily } \\
\text { decisions such as food. } \\
\text { Success has been higher for } \\
\text { specific interventions such as } \\
\text { promotion of breastfeeding. } \\
\text { A cultural shift in needed and } \\
\text { acceptance by providers and } \\
\text { care systems of their role in } \\
\text { basic behaviours }\end{array}$ & $\begin{array}{l}\text { How to synchronise provider } \\
\text { incentives for community } \\
\text { engagement and health } \\
\text { promotion in nutrition. How } \\
\text { to reach disadvantaged } \\
\text { groups }\end{array}$ & $\begin{array}{l}\text { A variety of approaches is needed } \\
\text { including integration of food } \\
\text { and nutrition into the electronic } \\
\text { health records, provider licensing } \\
\text { and specialty exams, continuing } \\
\text { medical education, and quality } \\
\text { metrics and reimbursement } \\
\text { standards; coverage of medically } \\
\text { tailored meals and F\&V } \\
\text { prescriptions for relevant patients; } \\
\text { testing of patient based inventive } \\
\text { and education programmes } \\
\text { for healthier eating using new } \\
\text { technologies; payment reform that } \\
\text { incentivises community health } \\
\text { and engagement; systematic } \\
\text { assessment and integration of } \\
\text { healthcare with public health; and } \\
\text { worksite wellness actions (see } \\
\text { above) for staff, patients, and } \\
\text { visitors }\end{array}$ \\
\hline $\begin{array}{l}\text { Food marketing } \\
\text { standards }\end{array}$ & $\begin{array}{l}\text { Limiting marketing } \\
\text { to children of foods } \\
\text { and beverages that } \\
\text { do not meet nutrition } \\
\text { standards }^{67.69}\end{array}$ & $\begin{array}{l}\text { These are low cost, can } \\
\text { be sustained, and are } \\
\text { recommended by many } \\
\text { organisations, especially } \\
\text { marketing to children up } \\
\text { to } 12 \text { years }\end{array}$ & $\begin{array}{l}\text { To be effective, they must } \\
\text { restrict all marketing in any } \\
\text { form to children, not just } \\
\text { on children's programmes, } \\
\text { because of widespread } \\
\text { exposure of children to } \\
\text { marketing in many formats }{ }^{70}\end{array}$ & $\begin{array}{l}\text { Potential legal and political } \\
\text { feasibility challenges exist. } \\
\text { Nanny state concern. } \\
\text { Non-traditional marketing } \\
\text { through websites, social } \\
\text { media, video games, } \\
\text { television shows, and } \\
\text { movies is growing, which } \\
\text { is much more difficult to } \\
\text { regulate. }\end{array}$ & $\begin{array}{l}\text { Standards for marketing to } \\
\text { children across all formats should } \\
\text { be considered and implemented } \\
\text { because of the evidence for effects } \\
\text { of marketing on food preferences } \\
\text { and dietary intakes, as well as } \\
\text { inability of young children to } \\
\text { discriminate between marketing } \\
\text { and regular programming }\end{array}$ \\
\hline $\begin{array}{l}\text { Local built } \\
\text { environment }\end{array}$ & $\begin{array}{l}\text { Zoning restrictions on } \\
\text { fast food outlets around } \\
\text { schools. }{ }^{71} \text { Building of } \\
\text { supermarkets in food } \\
\text { deserts. }{ }^{72} \text { Expanding } \\
\text { farmers' markets and } \\
\text { mobile produce vendors }\end{array}$ & $\begin{array}{l}\text { Clear conceptual } \\
\text { frameworks support } \\
\text { the importance of food } \\
\text { access and availability. } \\
\text { Public support and } \\
\text { often (for increasing } \\
\text { access) industry } \\
\text { support is strong. Can } \\
\text { advance equity goals } \\
\text { where investments in } \\
\text { infrastructure counter } \\
\text { historical disparities in } \\
\text { burden of disease and } \\
\text { investments }\end{array}$ & $\begin{array}{l}\text { Many such approaches have } \\
\text { not been rigorously studied. } \\
\text { Characterising availability } \\
\text { and accessibility is complex, } \\
\text { and often not simply related } \\
\text { to geographical distance or } \\
\text { density. Strong collaboration } \\
\text { between town/city planning } \\
\text { and businesses is needed }\end{array}$ & $\begin{array}{l}\text { Cause and effect of many } \\
\text { cross sectional relationships } \\
\text { is uncertain. Optimal metrics } \\
\text { to define access, availability, } \\
\text { and types of stores are } \\
\text { unclear }\end{array}$ & $\begin{array}{l}\text { This is a promising approach. } \\
\text { It relocates diet action within } \\
\text { ecological public health, and } \\
\text { reconnects with city planning. }^{73} \\
\text { More research is needed, including } \\
\text { implementation and evaluation } \\
\text { research }\end{array}$ \\
\hline
\end{tabular}




\begin{tabular}{|c|c|c|c|c|c|}
\hline Policy strategy & Examples & Strengths & Limitations & Uncertainties & Recommendations \\
\hline $\begin{array}{l}\text { Research and } \\
\text { innovation }\end{array}$ & $\begin{array}{l}\text { Basic science, medical, } \\
\text { and applied (including } \\
\text { policy) nutrition } \\
\text { research. Research and } \\
\text { development incentives } \\
\text { for agricultural producers } \\
\text { and food manufacturers }\end{array}$ & $\begin{array}{l}\text { Recognises that today's } \\
\text { challenges often require } \\
\text { tomorrow's solutions. } \\
\text { Can promote and use } \\
\text { industry innovation and } \\
\text { economic success, eg, } \\
\text { through tax breaks and } \\
\text { government approval. } \\
\text { Return on investment is } \\
\text { often high }\end{array}$ & $\begin{array}{l}\text { Is viewed as costly by some } \\
\text { policy makers. Length of time } \\
\text { to see benefits is uncertain }\end{array}$ & $\begin{array}{l}\text { Recognition of benefits by } \\
\text { policy makers and feasibility } \\
\text { in era of constrained } \\
\text { budgets. How to identify } \\
\text { and minimise conflicts of } \\
\text { interest for public-private } \\
\text { partnerships (see box 2) }\end{array}$ & $\begin{array}{l}\text { Government should substantially } \\
\text { increase and sustain funding for } \\
\text { research on food, nutrition, health, } \\
\text { and policy implementation and } \\
\text { evaluation is needed. Public- } \\
\text { private partnerships (eg, research } \\
\text { and development incentives) } \\
\text { to promote development and } \\
\text { marketing of healthier products } \\
\text { are needed }\end{array}$ \\
\hline $\begin{array}{l}\text { Coordination of } \\
\text { actions across } \\
\text { ministries, } \\
\text { agencies, and at } \\
\text { local, national, and } \\
\text { international levels }\end{array}$ & $\begin{array}{l}\text { Coordination of school, } \\
\text { after school, and early } \\
\text { child care meal standards } \\
\text { with national dietary } \\
\text { guidelines. }{ }^{49} \text { Integration } \\
\text { of food assistance } \\
\text { programmes with } \\
\text { healthcare for the poor. } \\
\text { Public school lunch and } \\
\text { breakfast programmes } \\
\text { to improve military } \\
\text { readiness and national } \\
\text { security. }{ }^{74} \text { Agricultural } \\
\text { and trade policy linked to } \\
\text { nutrition and health. }{ }^{75-77} \\
\text { Setting of nutrition } \\
\text { guidelines, policy actions, } \\
\text { and country goals by } \\
\text { global economic and } \\
\text { political institutions such } \\
\text { as the World Bank, United } \\
\text { Nations, and World Trade } \\
\text { Organisation }\end{array}$ & $\begin{array}{l}\text { A “nutrition and health } \\
\text { in all” approach could } \\
\text { greatly improve food } \\
\text { systems and health } \\
\text { outcomes, with large } \\
\text { benefits on productivity, } \\
\text { equity, and health } \\
\text { costs. Uses and adapts } \\
\text { existing government } \\
\text { structures and systems }\end{array}$ & $\begin{array}{l}\text { Expertise to combine and } \\
\text { stage policy approaches is } \\
\text { often limited. Jurisdiction for } \\
\text { different aspects of policies } \\
\text { may be divided across } \\
\text { government sectors, who may } \\
\text { also share unequally the costs } \\
\text { and benefits. Factors driving } \\
\text { policy for some outcomes (e., } \\
\text { employment, business profits) } \\
\text { may differ from those for } \\
\text { nutrition and health }\end{array}$ & $\begin{array}{l}\text { How to align different } \\
\text { government sectors with } \\
\text { historically different } \\
\text { priorities, stakeholders, and } \\
\text { cultures. Unclear time scale } \\
\text { of risks and benefits for } \\
\text { many actions }\end{array}$ & $\begin{array}{l}\text { A ministerial or cabinet leadership } \\
\text { position is needed with oversight } \\
\text { and budgetary authority for cross } \\
\text { agency food and nutrition policy. } \\
\text { Nutrition impact assessment for } \\
\text { all major government policies } \\
\text { (eg, similar to environmental } \\
\text { impact assessment now done in } \\
\text { many countries for environmental } \\
\text { concerns). Agricultural and trade } \\
\text { policies to promote cultivation, } \\
\text { transport, storage, trade, and sale } \\
\text { of healthier foods. Coordinated } \\
\text { nutrition policies with bordering } \\
\text { nations, close allies, and trade } \\
\text { partners }\end{array}$ \\
\hline
\end{tabular}

$\mathrm{F} \& \mathrm{~V}=$ fruits and vegetables.

*Based on advances in behavioural and policy science and our review and interpretation of the evidence, knowledge, and experiences. The policy strategies in this table are organised by domain of intervention. Variations of each strategy can be further characterised by level (eg, local, national, organisational), target (eg, consumer, industry), or mechanism (eg, altering consumer preference, food formulation, or food availability and accessibility) (box 1).

programmes, and school gardens are also promising strategies, although long term effects and cost-benefits are not yet rigorously evaluated. Worksite wellness programmes can not only improve health but also lower costs and increase productivity. In one analysis, every $\$ 1$ spent on worksite wellness programming was estimated to generate about $\$ 3.27$ in lower medical costs and $\$ 2.73$ in less absenteeism. ${ }^{55}$ However, relatively few long term worksite studies have evaluated the effects on diet, few rigorous cost effectiveness data are available, and increased employee turnover reduces the immediate incentives to businesses to invest in the health of their employees. ${ }^{34}$ Governments should invest in their own employee worksite wellness programming and pursue policies, such as guidelines and tax incentives, to promote the implementation and evaluation by private employers of worksite efforts for healthier eating.

Ironically, one of the least used settings to promote better nutrition is the healthcare system. Individual providers and health organisations face several barriers to nutrition promotion. To overcome these difficulties, governments should promote policies that support implementation of evidence informed actions within the healthcare system and with relevant partners such as community health workers, pharmacies, and other community based organisations. Useful strategies include multidisciplinary lifestyle programmes for conditions such as prediabetes, ${ }^{56}$ medically tailored meals for patients with complex chronic diseases, ${ }^{5758}$ prescriptions for fruit and vegetables for health promotion and disease prevention, ${ }^{59}$ and nutrition counselling during pregnancy and early childhood. Other important actions include: educating healthcare providers on food and nutrition, systematically introduced through national reform of medical and specialty licensing exams and continuing medical education; expansion of nutrition counselling services through new reimbursement strategies and task sharing with community partners; and inclusion of standardised clinic and mobile assessments of diet quality and food insecurity in electronic health records, which are needed to assess and integrate nutrition into treatment plans, evaluate new health system interventions, and inform performance and reimbursement systems. ${ }^{260-62}$ Expanding access to care through universal coverage or other national strategies can further increase the effect of nutrition policies on health.
Hospitals should be incentivised by new quality measures and reimbursement guidelines to implement worksite wellness and engage in community public health. ${ }^{63-66}$

Standards for marketing, such as limiting advertising to children of foods and beverages that do not comply with basic nutrition, are recommended by the World Health Organization and Institute of Medicine. ${ }^{67-69}$ Several countries currently implement different forms of marketing restrictions: for example, Chile has recently limited advertising and use of cartoon characters to market products to children that do not meet standards for added sugar, added saturated fats, and sodium. ${ }^{70}$

The media and policy makers have increasingly focused on the local food environment, such as clustering of fast food sellers around schools ${ }^{71}$ and absence of supermarkets in many neighbourhoods (termed "food deserts"). ${ }^{72}$ However, the actual cause and effect of many of the observed cross sectional relationships and the appropriate ways to characterise the complex facets of availability and accessibility are poorly characterised..$^{2-7}$

${ }^{73}$ Further investigation including implementation and evaluation research is needed to allow the development of 
more concrete recommendations on how to improve the local food environment.

Modern nutritional science is young, especially in relation to the risk of the main chronic diseases. ${ }^{186}$ Strong government funding for basic nutrition and applied research and innovation is essential to continue to develop evidence based priorities for dietary policies. Areas for investigation in the next decade, for example, include basic molecular pathways; diet-microbiomehost interactions; individual fatty acids and their lipid derivatives; prebiotics, probiotics, and fermentation; phenols and other bioactive compounds; personalised nutrition; and nutrition data ("big data"). Government funding should also make applied research a priority, including new technologies for nutritional assessment and behaviour change, and policy implementation and evaluation.

Governments should also promote the food industry's shift towards healthier foods, taking advantage of rapidly rising consumer demand. Tax incentives and other fiscal policies should promote research, development and marketing of healthier foods in the food industry, combined with (and potentially funded by) fiscal disincentives for marketing and promoting sugar sweetened beverages and junk foods. A programme of government funding and transparent public-private partnerships for nutrition research is also needed to help minimise conflicts of interest and perceived and real biases. ${ }^{8687}$

No single intervention can tackle the complexities of the current food system, and different approaches can be complementary and synergistic. ${ }^{2-7}$ For example, trade policy traditionally emphasises foreign direct investment, trade liberalisation, and privatisation to encourage private sector investment but the influence of such actions on the food environment can also have positive and negative effects on health. ${ }^{75-77}$ These interconnections support the importance of an integrated, government strategy that uses and adapts existing structures and systems. Ideally, actions should be coordinated between ministries, agencies, and at local, national, and international levels. Upstream agricultural, trade, research, and industry measures can be integrated with midstream school, worksite, healthcare, and other environmental approaches as well as downstream consumer efforts. Such a "nutrition and health in all" policies could greatly improve food systems and health, national productivity, equity, and health savings. Strong government leadership is essential to help deliver such a comprehensive, sustained, multitarget, and multilevel approach $^{.78}$

\section{Translation of evidence to policy action: needs and difficulties}

Local and national governments have important roles in bringing healthier food and food security to their populations. However, the path from knowledge to effective action requires capacity in several areas. To our knowledge no country has implemented a full range of updated, comprehensive, and evidence informed strategies to encourage a healthier and more equitable food system (table 1). Given the remarkable health and economic burden of diet related illness and the need for multistakeholder solutions, a coordinated national food and nutrition policy strategy should be a priority for all governments.

Government must have appropriate knowledge to translate evidence into policy action. This includes an evidence based assessment of what defines a healthy diet; an understanding of diet related health and risk distributions overall and in at-risk subpopulations; analyses of how poor diet affects non-health sectors such as private businesses or the military; and consideration of environmental and societal values such as sustainability, equity, and justice. Insufficient awareness of policy makers of these factors can be compounded by evolving science and conflicting media messages. For example, some policy strategies continue to emphasise reduction in total fat, total saturated fat, or total calories, rather than food type and quality, processing methods, additives, and diet patterns. ${ }^{1}$ ${ }^{88}{ }^{89} \mathrm{New}$ metrics are needed that allow the healthiness of food products to be compared on multiple nutrient criteria. ${ }^{37}$ In addition, tackling obesity is sometimes seen as the only goal of nutrition policy and programming, rather than improved diet quality and overall health and wellbeing. The evidence to support policy interventions is also different from that for interventions delivered to individuals. ${ }^{2-7}$ Interventions on high risk individuals can often be studied in randomised placebo controlled trials; in contrast, policy interventions on populations often cannot. Thus, predictive modelling, observational, quasi-experimental, and interventional studies, and surveillance data must feature more heavily in the standards of evidence required for policy change.

Government must have the capacity to intervene. This includes having an evidence informed plan, access to technical experts for implementation and evaluation, and adequate resources and authority to act in the required areas. For many governments, developing a comprehensive nutritional policy will be new and unfamiliar, and require acknowledgement of certain limitations of the current system. The expertise to combine and phase different policy approaches can be lacking. Jurisdiction and funding for different aspects of policies may be spread across government sectors and ministries, which may share unequally the costs and benefits. Budgets for technical policy work on nutrition are often tied to resources allocated for the prevention of chronic diseases, which is underfinanced given their health and economic burden. Surveillance systems for monitoring and evaluating nutrition trends and disparities are under resourced. For some promising policy actions, relevant data demonstrating the links between food policies and health, healthcare costs, disparities, and economic problems are often unavailable to policy makers at the right time or in the right format for policy action.

Government must have the will to act and the governance and partnerships to support action. This requires support from civil society and relevant private and other non-government actors to implement and sustain appropriate policies. Political willingness to act can be undermined by several factors. For example, factors driving government food production policy (eg, employment, short term business profits, and international competition) may be different from those driving nutrition policy (eg, health and healthcare costs). Although dietary shifts can have rapid effects on health, ${ }^{90-93}$ the perception that dietary interventions require long periods to achieve benefits may not coincide with political and budget cycles. Public opinion may also not support policies seen as intrusive. ${ }^{94}$ Identified dietary priorities may not match public priorities and sentiment, nor agency authority for action. Industry opposition can be a major barrier, including political lobbying and marketing campaigns to fight policies they consider unfavourable. ${ }^{95}$ When policies are passed, lack of implementation because of limited resources, management, and accountability can greatly limit their effect, ${ }^{96}$ as in the case of school food standards in Mexico or quality standards to limit industrial trans fats in India.

\section{Other stakeholders}

Other stakeholders should promote, facilitate, and complement government policy 
Box 2:Lessons from interactions between public and private stakeholders in food and nutrition

Engagement with multiple actors is essential for the implementation of effective policies and programmes to tackle obesity and other chronic diseases. Clear rules are needed to manage conflicts of interest.

A recent report of the UK Health Forum analysed examples of international public-private interactions for food and nutrition policies for the prevention of chronic diseases. ${ }^{99}$ The report sheds light on relationships between government, civil society, academia, and the food and beverage industry and the need to strengthen governance for the identification and management of conflicts of interest that may arise. ${ }^{100}$

While the cases vary in their geographical and sociopolitical contexts and objectives, common themes are seen:

- Interactions between public and commercial sectors are numerous and diverse

- Transparency and documentation of these interactions are often limited

- Corresponding risks are neither assessed nor managed before or during such public-private interactions.

In Mexico a multistakeholder effort to monitor, evaluate and provide feedback on policies for the prevention and control of obesity and diabetes ${ }^{101}$ showed that providing the commercial sector privileged access over public health and civil society led to biased conclusions influenced by commercial interests. Other cases in Chile, Brazil, Mexico, Fiji, Canada, Spain, and England show that conflicts of interest can undermine effective policy. Many examples exist of companies that produce sugar sweetened beverages and junk food putting up strong resistance and lobbying to counter national policy actions for obesity prevention. These include shifting the blame for obesity and chronic diseases away from specific products and towards physical inactivity and energy balance, and the use of multistakeholder coalitions to shape policy that benefits commercial interests. In Fiji and other countries industry self regulation was not effective and was used by the food industry to rebut government efforts to implement recommended public health policies. ${ }^{102}$

\section{Specific lessons learnt about public-private interactions for policy and practice include:}

- Need for governance principles in multistakeholder platforms. Governments have a duty to ensure that interests not in the public good do not influence the individuals or institutions responsible for public decision making, and preserving integrity and public trust. Multistakeholder platforms should have guidelines on conflict of interest identification, management, and protection. Governments should establish guidelines about participants in groups that are responsible for policy design. Otherwise, such platforms may stall regulation and policy by suggesting agreement among civil society, government, and industry when there are in fact disagreements. ${ }^{101} 103$

- Need for regulations on lobbying. Lobbying strategies can greatly affect health policy decisions. ${ }^{104}$ In many countries, lobbying activities and corporate financing of politicians and political parties are loosely regulated. Strong regulations on transparency and activities are needed to maintain effective, unbiased policy making.

- Need for standards on public-private partnership. Given widespread recommendations for public-private alliances and partnerships to support the achievement of global health and development goals, governance of public-private partnerships is important to ensure that efforts to improve food and nutrition are in line with ethical, transparency, and accountability principles. For instance, the food and beverage industry should not participate in decision making on the design, implementation, or evaluation of obesity prevention policies. Their voice should be heard but decisions should be made by those without commercial interests.

- Need for more than self regulation. Industry self regulation is not sufficient to advance public health goals. Additional government regulation and standards are important to enforce the implementation of health related food and nutrition policies.

The case studies also highlight the need for scientific evidence free of conflicts of interest. Particularly in the cases of sugar sweetened beverages and junk foods, commissioning studies with strong ties to or funding from the food and beverage industry is a risk. ${ }^{105}$ Independent, peer reviewed scientific research is important to help inform policy making with the best available evidence. When industry does play a role in research studies, the involvement should be transparent.

Analysis of these case studies indicates a need to address conflict of interest and industry influence in health and nutrition policy making. WHO recently published draft guidance for the prevention and management of conflicts of interest in policy development and implementation of national nutrition programmes. ${ }^{106}$ Governments, academia and civil society all play an important role. In addition, further research is needed on how to identify, study, and minimise conflicts of interest in food and nutrition policy.

efforts. ${ }^{25219798}$ Academia should prioritise research on optimal dietary targets and cost effective policies; monitor and evaluate health indicators and policy outcomes; engage with communities, advocacy groups, the media, business, and policy makers; and inform and evaluate government and industry efforts. Health systems, clinicians, and insurers should implement strategies on patient behaviour change; advocate for broad changes in health systems to support these efforts; and engage with local communities. Employers, communities, schools, hospitals, and religious congregations should implement organisational strategies for healthier eating. Advocacy groups should partner with scientists to disseminate best practices and hold government and industry accountable for meaningful action.

Large multinational companies frequently have a great influence because of their economic power, government lobbying, and communication and marketing resources. Unclear or variably enforced government provisions on conflicts of interest can further increase industry influence. More directly, certain food companies have actively opposed policies about healthier foods, ${ }^{95}$ especially in low and middle income countries. ${ }^{96}$ Because multiple actors must be involved in effective nutrition policies and programmes, transparent rules of engagement are needed for public-private interactions (box 2). The food industry must be a facilitator for, not a barrier to, healthy food policies and use their expertise, scale, innovation, and marketing to develop, distribute, and market healthier foods, and create transparent, sincere partnerships with academics, advocacy groups, and government. ${ }^{87100101}$ To achieve this, the food industry's ultimate success ought to be linked to the distribution of healthy, optimally processed foods in a sustainable, equitable, and profitable way.

Given the scale of the problem and the multinational nature of the food industry, global public health efforts can complement national and local 
Box 3:Recommended government roles and actions for a healthier food system

\section{Systems can change when:}

- Recognise that good nutrition is a priority for local, national, and global health, equity, and economic security

- Acknowledge the importance of multilevel approaches, not “magic bullets", in order to implement strategic, coordinated government action. Based on current evidence, the best approaches are:

○ Fiscal incentives/disincentives (eg, taxes and subsidies) for consumers, the food industry, and organisations (eg, worksites)

- Prioritisation of both food security and nutritional quality in food assistance programmes

- Appropriate standards for additives including trans fat, sodium, and added sugars

- Procurement standards for all government food purchases and venues including food assistance programmes

○ Use of schools and worksites to promote healthier eating

- Incorporation of food and nutrition into the healthcare system at all levels

- Nutrition standards for marketing of foods and beverages to children

○ Front-of-pack labelling of evidence informed metrics such as overall fat quality (eg, unsaturated to saturated fat ratio), carbohydrate quality (eg, carbohydrate to fibre ratio), and sodium

- Implement policies using the best available evidence, which also provides an opportunity to build further evidence for better decision making by evaluation of the policies being implemented

- Emphasise strategies with the greatest potential to reduce social and racial/ethnic disparities from clustering of suboptimal diet habits, local environments, and disease risk factors

- Increase support for food and nutrition research to ensure that both dietary targets and policy efforts are scientifically sound

- Support public-private partnerships with the food industry and other major non-food businesses (eg, private health and life insurance, and self insured corporations) for research and development on healthier products, effective behaviour change, and other common aims. This must include development of clear and transparent policies to identify and minimise conflicts of interest (see box 2)

- Facilitate participation of other stakeholders in policy development, implementation, and evaluation

- Incorporate nutrition and health in all of government, for example, city planning, economic development, agricultural and trade policies, and nutrition impact assessment

- Link nutrition and food policies to economic and production indices such as the influence of diet related illness and health on production and the economy

- Create a ministerial or cabinet leadership position with oversight and budgetary authority for cross agency food and nutrition policy

- Support monitoring and evaluation of nutrition habits, food systems, and corresponding policies including for individuals, communities, and larger systems. Link to and use existing surveillance systems (eg, healthcare) as well as new technologies (eg, social media, and personal monitors)

- Identify and use complementary global public health activities (eg, the United Nations Sustainable Development Goals), including to bring stakeholders together and, where necessary, counter the food industry

government activities. International economic and political institutions, including the World Bank, United Nations, and World Trade Organisation, must play a more assertive role. Actions should include developing and measuring adherence to nutrition policy standards; coordinating efforts of member country; assisting governments as needed with design, implementation, and evaluation of food policies; bringing stakeholders together including global agribusiness, restaurant chains, and food manufacturers; and providing a countervailing force to multi-national food industry lobbying.

\section{Conclusions and recommendations}

Because multisectoral approaches are necessary to create healthier food systems, ${ }^{5}$ governments should actively develop and implement policies to promote strategic and sustained change. We recommend several specific government roles and actions (box 3). For each, governments should assess whether the implemented strategies have the intended effects, identify and tackle disparities, and detect unintended consequences. This information should be made accessible to the public, academia, and other organisations.

The development and implementation of effective nutrition policies by governments have been hindered in the past by several factors, including insufficient knowledge, capacity, and will. Action and advocacy by many stakeholders are needed to overcome these barriers. Past successes that can point the way forward include effective public health approaches to complex problems such as tobacco use, motor vehicle crashes, and occupational safety. These have been achieved through a combination of scientific progress, public awareness and advocacy, consumer demand, industry innovation, government regulation, and cultural change. These successes provide a template for a healthier food system, that is: address the consumer, the product (agricultural commodities, foods, and beverages), the environment (retailers, cafeterias, and restaurants), and the culture (unhealthy eating, and marketing). To be successful, broad alliances are often required to maintain pressure, provide sound data, and bring about the desire for progress. Strong government policy is crucial to achieve a healthy, profitable, equitable, and sustainable food system that benefits all.

Correspondence to: D Mozaffarian dariush. mozaffarian@tufts.edu

Contributors and sources: DM conceived the paper and is the guarantor. All authors contributed to drafting the manuscript and critical revision of the manuscript for important intellectual content, and approved the final manuscript. The authors selected the literature for inclusion in this manuscript based on their own expertise and knowledge, discussions with colleagues, and editorial and reviewer comments.

Competing interests: All authors have read and understood BMJ policy on declaration of interests and declare funding from the National Institutes of Health, NHLBI (R01 HL130735). The funders had no role in the design or conduct of the study; collection, management, analysis, or interpretation of the data; preparation, review, or approval of the manuscript; or decision to submit the manuscript for publication DM reports personal fees from Acasti Pharma, GOED, DSM, Nutrition Impact, Pollock Communications, Bunge, Indigo Agriculture, and Amarin; scientific advisory board, Omada Health, Elysium Health, and DayTwo; and chapter royalties from UpToDate (not related to this work). JAR reports personal fees from Tres Montes Lucchetti, not related to this work.

Provenance and peer review: Commissioned; externally peer reviewed.

This article is one of a series commissioned by The $B M J$. Open access fees for the series were funded by Swiss Re, which had no input into the commissioning or peer review of the articles. The BM/ thanks the series advisers, Nita Forouhi and Dariush Mozaffarian, 
for valuable advice and guiding selection of topics in the series.

\section{Dariush Mozaffarian, dean ${ }^{1}$}

Sonia Y Angell, deputy commissioner ${ }^{2}$

Tim Lang, professor ${ }^{3}$

Juan A Rivera, director

${ }^{1}$ Friedman School of Nutrition Science and Policy, Tufts University, Boston MA, USA

${ }^{2}$ New York City Department of Health and Mental Hygiene, New York City NY, USA

${ }^{3}$ School of Arts and Social Sciences, City University of London, UK

${ }^{4}$ Instituto Nacional de Salud Pública, Mexico City, Mexico

1 Mozaffarian D, Rosenberg I, Uauy R. History of modern nutrition science-implications for current research, dietary guidelines, and food policy. BMJ 2018;361:k2392.

2 Afshin A, Micha R, Khatibzadeh S, Schmidt LA, Mozaffarian D. Dietary policies to reduce noncommunicable diseases. In: Brown GW, Yamey G, Wamala S, eds. The handbook of global health policy. 1st ed. Wiley, 2014:175-93. doi:10.1002/9781118509623.ch9

3 Mozaffarian D, Afshin A, Benowitz NL, et al, American Heart Association Council on Epidemiology and Prevention, Council on Nutrition, Physical Activity and Metabolism, Council on Clinical Cardiology, Council on Cardiovascula Disease in the Young, Council on the Kidney in Cardiovasc. Population approaches to improve diet, physical activity, and smoking habits: a scientific statement from the American Heart Association. Circulation 2012;126:1514-63. doi:10.1161/ CIR.0b013e318260a20b

4 Afshin A, Penalvo J, Del Gobbo L, et al. CVD prevention through policy: a review of mass media, food/menu labeling, taxation/subsidies, built environment, school procurement, worksite wellness, and marketing standards to improve diet. Curr Cardiol Rep 2015;17:98. doi:10.1007/s11886-015-0658-9

5. World Cancer Research Fund International. NOURISHING framework. 2017. https://www.wcrf. org/int/policy/nourishing-database

6 Informas. The Healthy Food Environment Policy Index (Food-EPI). 2017. http://www.informas.org/food-epi/

7 Food-PRICE. Food Policy Review and Intervention Cost-Effectiveness (Food-PRICE). 2018. https://www. food-price.org/

8 Brug J. Determinants of healthy eating: motivation, abilities and environmental opportunities. Fam Pract 2008;25(Suppl 1):i50-5. doi:10.1093/fampra/ cmn063

9 van’t Riet J, Sijtsema SJ, Dagevos H, De Bruijn G]. The importance of habits in eating behaviour. An overview and recommendations for future research. Appetite 2011;57:585-96. doi:10.1016/j. appet.2011.07.010

10 Nehring I, Kostka T, von Kries R, Rehfuess EA. Impacts of in utero and early infant taste experiences on later taste acceptance: a systematic review. / Nutr 2015;145:1271-9. doi:10.3945/ jn.114.203976

11 Liem DG, Mennella JA. Sweet and sour preferences during childhood: role of early experiences. Dev Psychobiol 2002;41:388-95. doi:10.1002/ dev.10067

12 DiSantis KI, Collins BN, Fisher JO, Davey A. Do infants fed directly from the breast have improved appetite regulation and slower growth during early childhood compared with infants fed from a bottle? Int / Behav Nutr Phys Act 2011;8:89. doi:10.1186/1479-58688-89

13 Robinson TN. Reducing children's television viewing to prevent obesity: a randomized controlled trial. JAMA 1999;282:1561-7. doi:10.1001/ jama.282.16.1561

14 Epstein LH, Roemmich JN, Robinson JL, et al. A randomized trial of the effects of reducing television viewing and computer use on body mass index in young children. Arch Pediatr
Adolesc Med 2008;162:239-45. doi:10.1001/ archpediatrics.2007.45

15 Mozaffarian D, Hao T, Rimm EB, Willett WC, Hu FB. Changes in diet and lifestyle and longterm weight gain in women and men. N Engl Med 2011:364:2392-404 doi:10.1056/ NEJMoa1014296

16 Patel SR, Hu FB. Short sleep duration and weight gain: a systematic review. Obesity (Silver Spring) 2008;16:643-53. doi:10.1038/ oby. 2007.118

17 Brug |, Kremers SP, Lenthe Fv, Ball K, Crawford D. Environmental determinants of healthy eating: in need of theory and evidence. Proc Nutr Soc 2008;67:307-16. doi:10.1017 S0029665108008616

18 Taylor AL, Jacobson MF. Carbonating the world: the marketing and health impact of sugar drinks in lowand middle-income countries. Center for Science in the Public Interest, 2016

19 Mozaffarian D. Salt, sugar, and fat or branding, marketing, and promotion? Lancet 2013;382:1322 3. doi:10.1016/S0140-6736(13)62129-7

20 Bernhardt AM, Wilking C, Adachi-Mejia AM, Bergamini E, Marijnissen J, Sargent JD. How television fast food marketing aimed at children compares with adult advertisements. PLoS One 2013:8:e72479. doi:10.1371/journal.pone.0072479

21 Nugent R. Bringing agriculture to the table: how agriculture and food can play a role in preventing chronic disease. The Chicago Council on Global Affairs, 2011.

22 Mason P, Lang T. Sustainable diets. Routledge Earthscan, 2017.

23 Lang T, Rayner G. Beyond the Golden Era of public health: charting a path from sanitarianism to ecological public health .Public Health 2015;129:1369-82. doi:10.1016/j. puhe.2015.07.042

24 Huang Y, Pomeranz J, Wilde P, et al. Adoption and design of emerging dietary policies to improve cardiometabolic health in the US. Curr Atheroscler Rep 2018;20:25. doi:10.1007/s11883-018-0726-x

25 U.S. Department of Agriculture, U.S. Department of Health and Human Services. 2015-2020 Dietary Guidelines for Americans. Secondary 2015-2020 Dietary Guidelines for Americans 2015. https:// health.gov/dietaryguidelines/2015/guidelines/.

26 Stables GJ, Subar AF, Patterson BH, et al. Changes in vegetable and fruit consumption and awareness among US adults: results of the 1991 and 19975 A Day for Better Health Program surveys. J Am Die Assoc 2002;102:809-17. doi:10.1016/S00028223(02)90181-1

27 Puska P, Tuomilehto J, Nissinen A, Vartiainen E, eds. The North Karelia Project: 20 years results and experiences. National Public Health Institute and World Health Organization Regional Office for Europe, 1995

28 World Health Organization, Food and Agriculture Organization. Preparation and use of food-based dietary guidelines: Report of a Joint FAO/WHO Consultation. WHO,1998.

29 Dietary Guidelines Advisory Committee. Scientific Report of the 2015 Dietary Guidelines Advisory Committee. Secondary Scientific Report of the 2015 Dietary Guidelines Advisory Committee 2015. http:// www.health.gov/dietaryguidelines/2015-scientificreport/

30 U.S. Food and Drug Administration. Changes to the Nutrition Facts Label. Secondary Changes to the Nutrition Facts Label 2016. http:// www.fda.gov/Food/GuidanceRegulation/ GuidanceDocumentsRegulatorylnformation LabelingNutrition/ucm385663.htm\#Summary

31 Littlewood JA, Lourenço S, Iversen CL, Hansen $\mathrm{GL}$. Menu labelling is effective in reducing energy ordered and consumed: a systematic review and meta-analysis of recent studies. Public Health Nutr 2016;19:2106-21. doi:10.1017/ S1368980015003468

32 Long MW, Tobias DK, Cradock AL, Batchelder H, Gortmaker SL. Systematic review and meta-analysis of the impact of restaurant menu calorie labeling.
Am J Public Health 2015;105:e11-24. doi:10.2105/ AJPH.2015.302570

33 VanEpps EM, Roberto CA, Park S, Economos CD, Bleich SN. Restaurant Menu Labeling Policy: Review of Evidence and Controversies. Curr Obes Rep 2016:5:72-80 doi:10.1007/s13679-016 0193-z

34 Shangguan S, Smith J, Ma W, Tanz L, Afshin A, Mozaffarian D. Effectiveness of point-of-purchase labeling on dietary behaviors and nutrient contents of foods: A systemic review and meta-analysis (abstract). Circulation 2015:131(Suppl 1):AP323-AP23.

35 Graham DJ, Jeffery RW. Location, location, location: eye-tracking evidence that consumers preferentially view prominently positioned nutrition information. / Am Diet Assoc 2011:111:1704-11. doi:10.1016/j. jada.2011.08.005

36 Spence C, Okajima K, Cheok AD, Petit O, Michel C. Eating with our eyes: From visual hunger to digital satiation. Brain Cogn 2016;110:53-63. doi:10.1016/j.bandc.2015.08.006

37 Nutrisavings. The Nutrisavings scoring system. 2016 http://media.nutrisavings.com/Print/white-paper-v4 pdf.

38 Pomeranz JL, Wilde P, Huang Y, Micha R, Mozaffarian D. Legal and administrative feasibility of a federal junk food and sugar-sweetened beverage tax to improve diet. Am J Public Health 2018;108:203-9. doi:10.2105/AIPH.2017.304159

39 Colchero MA, Rivera-Dommarco J, Popkin BM, Ng SW. Delivery system innovation in Mexico, evidence of sustained consumer response two years after implementing a sugar-sweetened beverage tax. PLOS Med 2016;13:e1002057. doi:10.1371/journal. pmed.1002057

40 Batis C, Rivera JA, Popkin BM, Taillie LS. Firstyear evaluation of Mexico's tax on nonessential energy-dense foods: an observational study. PLOS Med 2016;13:e1002057. doi:10.1371/journal. pmed.1002057https://www.ncbi.nlm.nih.gov/ entrez/query.fcgi?cmd=Retrieve\&db=PubMed\&li st_uids=27379797\&dopt=Abstract

41 Olsho LE, Klerman JA, Wilde PE, et al, Financial incentives increase fruit and vegetable intake among Supplemental Nutrition Assistance Program participants: a randomized controlled trial of the USDA Healthy Incentives Pilot. Am J Clin Nutr 2016;104:423-35. doi:10.1016/j. ypmed.2015.03.019

42 US Department of Agriculture. Food Insecurity Nutrition Incentive (FINI) Grant Program. Secondary Food Insecurity Nutrition Incentive (FINI) Grant Program 2016. https://nifa.usda.gov/program/foodinsecurity-nutrition-incentive-fini-grant-program

43 US Department of Agriculture. Supplementa Nutrition Assistance Program Participation and Costs. Secondary Supplemental Nutrition Assistance Program Participation and Costs 2018. https:// fns-prod.azureedge.net/sites/default/files/pd/ SNAPsummary.pdf

44 Bipartisan Policy Center. Leading with Nutrition: Leveraging Federal Programs for Better Health. 2018. http://www.bipartisanpolicy.org/SNAP

45 Public Health England. Guidelines on reducing sugar in food published for industry. 30 March 2017 2017. https://www.gov.uk/government/news/ guidelines-on-reducing-sugar-in-food-published-forindustry

46 U.S. Food and Drug Administration. Final determination regarding partially hydrogenated oils. Federal Register 2015. June 17, 2015; 80 FR 34650. https://federalregister.gov/a/2015-14883

47 He FJ, Pombo-Rodrigues S, Macgregor GA. Salt reduction in England from 2003 to 2011: its relationship to blood pressure, stroke and ischaemic heart disease mortality. BM Open 2014;4:e004549. doi:10.1136/bmjopen2013-004549https://www.ncbi.nlm.nih.gov/ entrez/query.fcgi?cmd=Retrieve \&db=PubMed\&li st_uids=24732242\&dopt=Abstract

48 Nuffield Council on Bioethics. Public health: ethical issues. Cambridge UK: Cambridge Publishers / Nuffield Council on Bioethics, 2007 http:// nuffieldbioethics.org/project/public-health/ 
49 Micha R, Karageorgou D, Bakogianni I, et al. Effectiveness of school food environment policies on children's dietary behaviors: A systematic review and meta-analysis. PLoS One 2018;13:e0194555. doi:10.1371/journal.pone.0194555

50 Afshin A, Babalola D, Mclean M, et al. Information Technology and Lifestyle: A Systematic Evaluation of Internet and Mobile Interventions for Improving Diet, Physical Activity, Obesity, Tobacco, and Alcohol Use. J Am HeartAssoc 2016;5:e003058. doi:10.1161/ JAHA.115.003058

51 Mazzocchi M, Traill WB, Shogren JF. Fat economics: Nutrition, health and economic policy. Oxford University Press, 2009. doi:10.1093/acprof:0 so/9780199213856.001.0001.

52 Brambila-Macias J, Shankar B, Capacci S, et al. Policy interventions to promote healthy eating: a review of what works, what does not, and what is promising. Food Nutr Bull 2011;32:365-75. doi: $10.1177 / 156482651103200408$

53 Lang T, Rayner G, Kaelin E. The Food Industry, Diet, Physical Activity and Health: a review of reported commitments and practice of 25 of the world's largest food companies. Report to the World Health Organization. City University Centre for Food Policy, 2006.

54 Shrestha A, Karmacharya BM, Khudyakov P, Weber MB, Spiegelman D. Dietary interventions to prevent and manage diabetes in worksite settings: a meta-analysis. J Occup Health 2018;60:31-45. doi:10.1539/joh.17-0121-RA

55 Baicker K, Cutler D, Song Z. Workplace wellness programs can generate savings. Health Aff (Millwood) 2010;29:304-11. doi:10.1377/ hlthaff.2009.0626

56 National Institute of Diabetes and Digestive and Kidney Diseases, National Institutes of Health. Diabetes Prevention Program (DPP). Secondary Diabetes Prevention Program (DPP). https://www. niddk.nih.gov/about-niddk/research-areas/diabetes/ diabetes-prevention-program-dpp/Pages/default. aspx.

57 Palar K, Napoles T, Hufstedler LL, et al. Comprehensive and medically appropriate food support is associated with improved HIV and diabetes health. J Urban Health 2017;94:87-99. doi:10.1007/s11524-016-0129-7

58 Berkowitz SA, Terranova J, Hill C, et al. Meal delivery programs reduce the use of costly health care in dually eligible medicare and medicaid beneficiaries. Health Aff (Millwood) 2018;37:53542. doi:10.1377/hlthaff.2017.0999

59 Wave W. Wholesome wave: how we work - produce prescriptions. 2017. https://www.wholesomewave org/how-we-work/produce-prescriptions (accessed April 4, 2018).

60 Bodenheimer T. Helping patients improve their health-related behaviors: what system changes do we need? Dis Manag 2005;8:319-30. doi:10.1089/ dis.2005.8.319

61 Simpson LA, Cooper J. Paying for obesity: a changing landscape. Pediatrics 2009;123(Suppl 5):S301-7. doi:10.1542/peds.2008-2780

62 Spring B, Ockene JK, Gidding SS, et al, American Heart Association Behavior Change Committee of the Council on Epidemiology and Prevention, Council on Lifestyle and Cardiometabolic Health, Council for High Blood Pressure Research, and Council on Cardiovascular and Stroke Nursing. Better population health through behavior change in adults: a call to action. Circulation 2013;128:2169-76. doi:10.1161/01 cir.0000435173.25936.e1

63 Ingram R, Scutchfield FD, Costich JF. Public health departments and accountable care organizations: finding common ground in population health. Am J Public Health 2015;105:840-6. doi:10.2105/ AJPH.2014.302483

64 Shaw FE, Asomugha CN, Conway PH, Rein AS. The Patient Protection and Affordable Care Act: opportunities for prevention and public health. Lancet 2014;384:75-82. doi:10.1016/S01406736(14)60259-2
65 U.K. National Health Service. NHS hospital services Hospital food standards. 2016. https://www.nhs. uk/NHSEngland/AboutNHSservices/NHShospitals/ Pages/hospital-food-standards.aspx

66 Health care without harm. 2018. https://noharm.or

67 World Health Organization. Set of recommendations on the marketing of foods and non-alcoholic beverages to children. 2010. http://www.who.int/ dietphysicalactivity/publications/recsmarketing/en/

68 Institute of Medicine. Challenges and opportunities for change in food marketing to children and youth: Workshop summary. The National Academies Press, 2013.

69 World Health Organization. A framework for implementing the set of recommendations on the marketing of foods and non-alcoholic beverages to children. 2012. http://www.who.int/ dietphysicalactivity/MarketingFramework2012.pdf

70 Jacobs A, The New York Times. In sweeping war on obesity, Chile slays Tony the Tiger. 2018. https:// www.nytimes.com/2018/02/07/health/obesitychile-sugar-regulations.htm

71 Mayor of London. Mayor cracks down on opening of new hot-food takeaways around schools. https:// www.london.gov.uk/press-releases/mayoral/mayorcracks-down-on-new-takeaways-near-schools. Greater London Assembly, 2017

72 Richardson AS, Ghosh-Dastidar M, Beckman R, et al. Can the introduction of a full-service supermarket in a food desert improve residents' economic status and health? Ann Epidemiol 2017;27:771-6. doi:10.1016/j.annepidem.2017.10.011

73 Rayner G, Lang T. Ecological public health: reshaping the conditions for good health. Routledge/Earthscan, 2012.

74 U.S. Department of Agriculture, Food and Nutrition Service. National School Lunch Act. 1946. https:// www.fns.usda.gov/nslp/history_5

75 Thow AM. Trade liberalisation and the nutrition transition: mapping the pathways for public health nutritionists. Public Health Nutr 2009;12:2150-8. doi:10.1017/S1368980009005680

76 Friel S, Hattersley L, Snowdon W, et al, INFORMAS. Monitoring the impacts of trade agreements on food environments. Obes Rev 2013;14(Suppl 1):120-34 doi:10.1111/obr.12081

77 Popkin BM, Reardon T. Obesity and the food system transformation in Latin America .Obes Rev 2018 Apr 24. doi:10.1111/obr.12694

78 Mozaffarian D, Blashek JA, Stavridis J. Learning from soft power. BMJ 2015;351:h4645. doi:10.1136/ bmj.h4645

79 Pearson-Stuttard J, Bandosz P, Rehm CD, et al. Comparing effectiveness of mass media campaigns with price reductions targeting fruit and vegetable intake on US cardiovascular disease mortality and race disparities. Am / Clin Nutr 2017;106:199-206. doi:10.3945/ajen.116.143925

80 Pearson-Stuttard J, Bandosz P, Rehm CD, et al. Reducing US cardiovascular disease burden and disparities through national and targeted dietary policies: A modelling study. PLoS Med 2017;14:e1002311. doi:10.1371/journal. pmed.1002311

81 Wan L, Watson E. R. A. Sugar taxes: The global picture in 2017. 2017. https://www.beveragedaily.com/ Article/2017/12/20/Sugar-taxes-The-global-picturein-2017

82 Lederer A, Curtis CJ, Silver LD, Angell SY. Toward a healthier city: nutrition standards for New York City government. Am I Prev Med 2014:46:423-8. doi:10.1016/j.amepre.2013.11.011

83 Angell SY, Silver LD, Goldstein GP, et al. Cholestero control beyond the clinic: New York City's trans fat restriction. Ann Intern Med 2009;151:129-34. doi:10.7326/0003-4819-151-2-200907210 00010

84 Angell SY, Farley TA. Can we finally make progress on sodium intake? Am J Public Health 2012;102:1625 7. doi:10.2105/AJPH.2012.300722

85 Curtis C), Clapp J, Niederman SA, Ng SW, Angell SY. US Food Industry Progress During the National Salt Reduction Initiative: 2009-2014. Am
Public Health 2016;106:1815-9. doi:10.2105/ AJPH.2016.303397

86 Mozaffarian D, Forouhi NG. Dietary guidelines and health-is nutrition science up to the task? BM/ 2018;360:k822. doi:10.1136/bmi.k822

87 Mozaffarian D. Conflict of interest and the role of the food industry in nutrition research. JAMA 2017;317:1755-6. doi:10.1001/ jama.2017.3456

88 Mozaffarian D, Ludwig DS. Dietary guidelines in the 21st century--a time for food. JAMA 2010;304:681 2. doi:10.1001/jama.2010.1116

89 Mozaffarian D. Foods, nutrients, and health: when will our policies catch up with nutrition science? Lancet Diabetes Endocrinol 2017;5:85-8. doi:10.1016/ S2213-8587(16)30265-0

90 Franco M, Orduñez P, Caballero B, et al. Impact of energy intake, physical activity, and populationwide weight loss on cardiovascular disease and diabetes mortality in Cuba, 1980-2005. Am J Epidemiol 2007;166:1374-80. doi:10.1093/aje/ kwm226

91 Zatonski W, Campos H, Willett W. Rapid declines in coronary heart disease mortality in Eastern Europe are associated with increased consumption of oils rich in alpha-linolenic acid. Eur Epidemiol 2008;23:3-10. doi:10.1007/s10654 007-9195-1

92 Capewell S, O’Flaherty M. Can dietary changes rapidly decrease cardiovascular mortality rates? Eur Heart / 2011;32:1187-9. doi:10.1093/eurheartj/ehr049

93 Estruch R, Ros E, Salas-Salvado J, et al. Primary prevention of cardiovascular disease with a Mediterranean diet. N Engl J Med 2013;368:127990. doi:10.1056/NEJMoa1200303

94 Frieden TR. Government's role in protecting health and safety. N Engl / Med 2013;368:1857-9. doi:10.1056/NEJMp1303819

95 Nestle M. Soda politics: taking on big soda (and winning). Oxford University Press, 2015.

96 UK Health Forum. Public health and the food and drinks industry: The governance and ethics of interaction. Lessons from research, policy and practice. 2017. http://www.ukhealthforum.org.uk/ EasysiteWeb/getresource.axd?AssetID=58303\&servi cetype $=$ Attachment

97 Institute of Medicine. Promoting cardiovascular health in the developing world: a critical challenge to achieve global health. The National Academies Press, 2010.

98 Hawkes C, Smith TG, Jewell J, et al. Smart food policies for obesity prevention. Lancet 2015;385:2410-21. doi:10.1016/S01406736(14)61745-1

99 Mwatsama M, ed. Public health and the food and drinks industry: The governance and ethics of interaction. Lessons from research, policy and practice. UK Health Forum, 2018.

100 Collins J, Afifi R, Gomes F. Conclusions. In: Mwatsama $\mathrm{M}$, ed. Public health and the food and drinks industry: The governance and ethics of interaction. Lessons from research, policy and practice. UK Health Forum, 2018:145-8

101 Barquera S, Sánchez-Bazan K, Carriedo A, Swinburn $B$. The development of a national obesity and diabetes prevention and control strategy in Mexico: actors, actions and conflicts of interest. In: Mwatsama M, ed. Public health and the food and drinks industry: The governance and ethics of interaction. Lessons from research, policy and practice. UK Health Forum, 2018:18-30.

102 Sharma N, Mialon M. Sugar-sweetened beverages, non-communicable diseases and the limits of selfregulation in Fiji. In: Mwatsama M, ed. Public health and the food and drinks industry: The governance and ethics of interaction. Lessons from research, policy and practice. UK Health Forum, 2018:39-45

103 Moscetti CW, Taylor AL. From participation to power: how the sugar- sweetened beverage industry shapes policy through multi-stakeholder coalitions. In: Mwatsama M, ed. UK Health Forum, 2018:102-9.

104 Cuadrado C, Valenzuela MT, Peña S. Conflicting goals and weakened actions: lessons learned from 
the political process of increasing sugar-sweetened beverage taxation in Chile. In: Mwatsama M, ed. Public health and the food and drinks industry: The governance and ethics of interaction. Lessons from research, policy and practice. UK Health Forum, 2018:31-8.

105 Chacon V, Benson P, Barnoya J. Designing a frontof-package labelling system to encourage healthier beverage choices in Guatemala. In: Mwatsama M, ed. Public health and the food and drinks industry: The governance and ethics of interaction. Lessons from research, policy and practice. UK Health Forum, 2018:89-95.

106 World Health Organization. Report by the

Director-General. Safeguarding against possible conflicts of interest in nutrition programmes: Draft approach for the prevention and management of conflicts of interest in the policy development and implementation of nutrition programmes at country level. WHO, 2017

Cite this as: BMJ 2018;361:k2426 http://dx.doi.org/10.1136/bmj.k2426

This is an Open Access article distributed in accordance with the Creative Commons Attribution Non Commercial (CC BY-NC 4.0) license, which permits others to distribute, remix, adapt, build upon this work non-commercially, and license their derivative works on different terms, provided the original work is properly cited and the use is non-commercial. See: http://creativecommons.org/licenses/by-nc/4.0/. 